\title{
Analysing The Quality Of Accrual Accounting Implementation In Indonesia Local Governments
}

\author{
Irwan Taufiq Ritonga \\ Faculty of Economics and Business, Universitas Gadjah Mada \\ irwanritonga@ugm.ac.id/abangupi@yahoo.com
}

\begin{abstract}
The main objective of this study is to assess the quality of accrual accounting implementation in Indonesia local governments. In the context of Indonesia local government, to the author's knowledge, this study is the first in proposing a concept to assess the quality of accrual accounting, which is based on the timeliness of transaction recognition. The quality of accrual accounting is assessed through five types of accrual transactions, which are converting assets to expenses transactions, accruing unpaid expenses transactions, accruing unpaid assets transactions, accruing uncollected revenues transactions, and converting liabilities to revenues transactions. This research is descriptive qualitative research because this research aims to provide facts about quality of accrual accounting implementation in Indonesia local government. The data used in this study is primary data in the form of questionnaires obtained directly from the respondents. The respondents of this study are people who have experience in preparing the local government financial statements. Results of this study are, first, the quality of accrual accounting implementation in Indonesia is low with the quality score of $48.57 \%$. Second, there is no significant difference in the quality of accrual accounting implementation in local government with unqualified opinions and local government with qualified opinions. Third, there is no significant difference in the quality of accrual accounting implementation among types of local governments, namely regency local government, municipal local government, and provincial local government.
\end{abstract}

Keywords: accrual accounting, local government, Indonesia

\section{INTRODUCTION}

The first year of accrual accounting implementation in Indonesia was in fiscal year 2015, both in central government and local government. Accounting entity and reporting entity must provide financial report based on Governmental Accounting Standards (GAS). Relating to accrual accounting implementation, in 2014 and 2015 The Supreme Audit Board (SAB)examined the preparation of central government and local government. The result showed that the preparation of both governments are not quite effective in supporting implementation of accrual accounting. It was caused by inadequate human resource, the less intensive socialization of GAS, accounting policy and system that have not been compiled yet, unintegrated system, no budget allocation especially for preparation and execution accrual accounting, organization structure that has not accommodate the execution of accrual accounting and there is plan for system development or financial management application (BPK RI, 2015). 
The implementation of accrual accounting is indeed not easy. Strong commitment of leader and capable human resources are really needed. Although some obstacles experience by some local governments, GAS accrual-based must be executed in fiscal year 2015. The findings of SAB about the readiness of government in implementing GAS accrual-based must be responsed by local governments so it would not affect to SAB opinion about the fairness of financial report (BPK RI, 2015). Based on that, the evaluation toward the implementation of accrual accounting become more important. The evaluation is expected to identify obstacles in implementing accrual accounting. Therefore, solutions and efforts to implement accrual accounting accordance with GAS needs to be found soon.

Nowadays, the implementation of accrual accounting in Indonesia is stepping to the third years. However, analysis quality of accrual accounting implementation is not done yet by any authorized institution, such as SAB, the Ministry of Finance, and Governmental Accounting Standards Committee. Based on the facts of the insufficient preparations in implementing accrual accounting and the absent of evaluation toward accrual accounting quality, the researchers are motivated to evaluate and analyze the quality of accrual accounting implementation in Indonesia local governments.

\section{LITERATURE REVIEW}

Accrual-based accounting. Accrual-based accounting is accounting that records financial transactions in the periods in which the transactions occur, without regard to the time of the receipt or payment of cash (Weygandt,Kimmel,\& Kieso, 2013). Therefore, on accrual basis, the entity recognizes the payables and receivables, either due to asset acquisition, income, or expenses. Assets are recognized when potential future economic benefits will flow to the entity and reliable measurement is possible. Revenue is recognized when the obligation was settled in the accounting period. Expenses are recognized when an attempt made to generate these revenues.

Trend of accrual accounting in the world. Accrual accounting has become the main theme in public sector accounting reformation for last three decades. Almost all articles discussing public sector accounting reformation or governmental accounting always associate it with change on accounting method from cash basis to accrual basis (Ouda, 2003). Therefore, many experts, for examples, Guthrie (1998), Paulsson (2006), Carlin (2005), Broadbent and Guthrie (1992), Pallot (1992), Robinson (1998), Wynne (2007), Christiaens and Rommel (2008), Peter van der Hoek (2005), Lapsley (1999), and Blöndal (2003), argue that accrual accounting is the trend which would applied in the world in the future.

There are three reasons that underlie accrual accounting idea as trend in the world. First, the International Federation of Accountants - Public Sector Committee (IFAC PSC) developed International Public Sector Accounting Standards (IPSAS) with based on accrual (Paulsson, 2006; Lapsley, Mussari and Paulsson, 2009; Marti, 2006; Pina and Torres, 2003; Wynne, 2008). Second, World Bank put reformation in public sector as important component in the Millennium Development Goals (MDG). Its fifth component is public management planning which detailed in administrative mechanism and governance. Public sector accounting reformation is one of the methods to execute the fifth component (James L Chan, 2006). Third, in accordance with that idea, developed 
country incorporated in the Organization for Economic Cooperation and Development (OECD) put the change cash basis to accrual basis as one of purposes of sector public financial management reformation (Wescott, 2008). Similarly, some of academic articles, for examples Ahn et al. (2014) and Blöndal (2003), argue that accrual accounting is the main trend in public sector accounting reformation and the development of accrual basis will continue for the next years (look Paulsson, 2006). This idea underlies the assumption which is believed by many experts, that embodiment of future public sector accounting is the concept of accrual accounting that developing nowadays.

Data stated by Blöndal (2003) shows that not many countries have been implementing accrual accounting. Blöndal (2003) provides information about variation implementation of governmental accounting in 29 developed country that joined Organization for Economic Cooperation and Development (OECD). Just five countries, which are Australia, New Zealand, Sweden, Switzerland, and Britain, that purely implementing full accrual. Even, Blöndal (2003) said that United States is categorized as country that is still using cash-based accounting with exception for some transactions are using accrual. Therefore, the majority of OECD members are still using cash based accounting.

Accrual accounting in Indonesia local government. Implementation of accrual accounting in Indonesia local government started by the issuance of Government Regulation No. 71 of 2010on Governmental Accounting Standards (GAS) on October $22^{\text {th }}, 2010$. This regulation was issued to fulfill Article 36, point 1 of Act No. 17 of 2003 and Article 70, point 2, Act No. 1 of 2004, that is explain about accrual accounting implementation in entity of government of Indonesia, both central government and local government. The scope of that regulation involves GAS accrual-based and GAS cashbased toward accrual. GAS accrual-based was effectively implemented since the date it was set, but it must be applied by all entities of governments started from fiscal year 2015 . Meanwhile, for government entities that not ready to implement it, they are allowed to implement GAS cash-based toward accrual up to fiscal year 2014. Year of 2010 until 2014 were the implementation transition from cash-based toward accrual to accrual-based. After that, in 2015 until present is the time for implementing accrual accounting.

In the context of Indonesia, accrual accounting is accounting that recognize operational revenue, expenses, assets, liabilities, and equity based on accrual-based, but recognize cash revenue, expenditure, and financing based on cash basis.

Quality of accrual accounting information. Local government financial reports should provide useful information to users in assessing accountability and in making decisions in economic, social, and political decisions. Therefore, accounting information must be qualified. Qualified accounting information should be relevant, reliable, comparable, and understandable (Government Regulation No. 71 of 2010).

Relevant information is information that has the feedback value, has a predictive value, on time, and complete. Reliable information is information that is free from misleading notions and material errors, presenting every fact fairly, and verifiable. Accounting information will be more useful if it can be compared, both with the previous period and with other reporting entities in general. The accounting information presented should be understandable to users and expressed in forms and terms tailored to the limits of user's understanding. 
In this study, the assessment of the quality of the accrual accounting implementation based on the time of recognition financial transaction. The more accurate the recognition time, the higher the quality of accrual.

Types of accrual transactions. There are five types of accrual transactions. Those five types are as follows:

Type A: Converting assets to expenses transactions. Examples for this type are inventory expense transaction (consumption of inventories), depreciation expense of fixed assetstransaction (consumption of fixed assets), amortization expense transaction (consumption of intangible assets), and converting prepaid expense to expense.

Type B: Accruing unpaid expenses transactions. Examples for this type are unpaid salaries and allowances expense transaction; unpaid overtime work fee expense transactions; unpaid utilities expense transactions; and cleaning services/security/catering expense transactions.

Type C: Accruing unpaid assets transactions. Examples for this type are unpaid acquisition of inventories transactions, unpaid acquisition of fixed assets transactions; and unpaid acquisition of intangible assets transactions.

Type D: Accruing uncollected revenues transactions. Examples for this type are uncollected tax revenues transactions, uncollected charges revenues transactions, uncollected dividend income transactions on investments, and uncollected interest revenues/fine revenues/claims revenues transactions.

Type E: Converting liabilities to revenues. Examples for this type are converting of prepaid income to revenue.

These typesare used for reference in arranging questionnaire in this study. Questionnaire used in this study is available in the appendix section.

Previous research related with assessment quality of accrual accounting. Research on the implementation of accrual accounting has been done by scholars. However, research on accrual accounting quality, especially in local government, is still rare. Chan (2003) measures the quality of the accrual accounting implementation based on the completeness of the types of elements of financial statements, namely:

1. mild accruals for accrual implementation on elements of short-term financial assets and short-term liabilities.

2. moderate accruals for accrual implementation on elements of flow assets, long-term financial assets, short-term debt, and long-term debt.

3. strong accruals for accrual implementation of elements of flow assets, long-term financial assets, fixed assets, short-term debt, long-term debt and contingent debt.

4. radical accruals for the accrual application of elements of flow assets, long-term financial assets, fixed assets, depreciation, short-term debt, long-term debt, contingent debt, and debt to social welfare facilities contained in the law.

The basis used by Chan (2003) in measuring the quality of the accrual accounting application is not in accordance with the definition of accrual accounting. Accrual accounting emphasizes the timeliness of financial transactions recognition, rather than emphasizing the completeness of the elements of financial statements.

In Indonesia, research on accrual accounting quality was first performed by Ismiyati and Ritonga (2016). Ismiyati and Ritonga (2016) evaluated the implementation of accrual accounting at five local governments (Sleman, Bantul, City of Yogyakarta, Special Region 
of Yogyakarta, and Karanganyar). Different from Chan (2003, see also Chan (2006)) that measures the quality of accruals based on the completeness of the elements of the financial statements, Ismiyati and Ritonga (2016) measure the accrual quality based on the timeliness of transaction recognition. Ismiyati and Ritonga (2016) concluded that the quality of implementation of accrual accounting in five local governments are low with variation from $38 \%$ to $70 \%$.

\section{RESEARCH METHOD}

Research approach. This research is descriptive qualitative research. The purpose is to give facts about the quality of accrual accounting implementation in Indonesia local government. This is in line with statement of Indriantoro and Supomo (2013) that said descriptive research examine facts of population. This research, author measures quality of accrual-based on timeliness of transaction recognition.

Data. Data used in this research is primary data in the form of questionnaires obtained directly from respondent. The questionnaires contains questions relates to quality of accrual accounting implementation. The questions ask about the recognition time of converting assets to expense, accruing unpaid expense, accruing unpaid assets, accruing uncollected revenues, and converting liabilities to revenues of local government. The questionnaires can be seen in appendix.

Data collection. The process of collecting data can be seen as below:

1. Author sent private message using Whatsapp to all members of group of local government accounting manager, asking their availability to be respondent. The number of member contacted were 167 persons.

2. If accounting manager is willing to be respondent, then author send questionnaires via email. The number which willing to be was 143 persons.

3. From 143 emails sent, there were 116 respondents that return questionnaires. The questionnaires were returned via Whatsapp or e-mail.

Population and respondent. The population of this research is 549 local government of Indonesia, that are 416 regency local government, 99 municipal local government, and 34 provincial local government. The sample of research consists of 55 regency local governments, 36 municipal local governments, and 25 provincial local governments. The sample selection method is using purposive sampling, that is based on availability of the member joined in Whatsapp social media group to participate. This group contain of local government accounting manager in Indonesia.

The respondent of this research is experienced people in making local government financial report. Their position at least is deputy accounting manager. They have joined in Whatsapp Group managed by Ministry of Domestic Affairs.

\section{Data analysis}

Phase 1: Analyzing the quality of accrual accounting implementation. Data analysis in this research carried out by the following steps:

1. Assign the value of each answer in the questionnaire with the following conditions: 
a. If the answer is "Yes" and there are four possible answers (i.e., a, b, c, and d), then the answer "a" rated 1; answer "b" rated 0.75; answer "c" rated 0.5; and the answer "d" rated 0.25 .

b. If the answer is "Yes" and there are 5 answer choices (i.e., a, b, c, d, and e), then the answer "a" rated 1; answer "b" rated 0.8; answer "c" rated 0.6; answer "d" rated 0.4; and answers "e" were given a value of 0.2 .

c. If the answer is "No", then it is not rated.

d. If in the number there are two questions, which question a and question b (e.g., questions $6 \mathrm{a}$ and $6 \mathrm{~b}$ ), then the question $\mathrm{b}$ is intended to confirm the answer in the question $\mathrm{a}$. If the answer to question a and question $\mathrm{b}$ are different, the respondents deemed inconsistent and is not rated.

2. Calculating the total value of each accrual transaction type by adding up the value of all the questions in the type of the accrual transaction.

3. Set a maximum value for each accrual transaction type, it's how the number of questions answered "Yes" to each type. Example:

a. In accrual transaction Type A, there are 4 questions. If all questions are answered "Yes", then the maximum value is 4. If there is one question is answered "No", then the maximum value is 3 (4-1).

b. In accrual transaction type $\mathrm{B}$, contained 4 number of questions (one number, there are two questions which question a and question $b$ ). If all the numbers are answered "Yes" and consistent between answers a and b, then the maximum value is 4 . If there is one question is answered "Yes" and inconsistent between answers a and b, then the maximum value is $3(4-1)$.

4. Calculating the percentage of each accrual transaction type by dividing the value of achievement (point 2) with a maximum value (point 3).

5. Calculating the total percentage of achievement by dividing the total value of achievement with total maximum value of all transaction types.

Measurement of the quality of accrual accounting implementation based on the time of recognition financial transaction, it is when transaction occurs, end of the month, end of quarter (March 31; June 30; September 30; December 31), the end of semester (June 30; December 31), or the end of the year (December 31). The more accurate the recognition time, the higher quality of accrual.

Phase 2: Further analysis. Data collected from phase 1 then analyzed:

1. Simple descriptive statistic, calculates the percentage of highest and lowest achievement rates on type of accrual transaction with the best and worst implementation quality and also calculate the percentage of total performance value to analyze the quality of accrualaccounting implementation in local government as a whole.

2. T-test to analyze the difference of accrualaccounting implementation in local government with unqualified opinion and qualified opinion.

3. Analysis of Variance (ANOVA) to analyzes the difference of accrual accounting implementation quality to all types local government (regency local government, municipal local government, and provincial local government). 


\section{RESULTS}

Quality of accrual accounting. The results of assessing quality of accrual accounting implementation in local government are presented in Table 1 below.

Table 1. Average score of accrual accounting quality

\begin{tabular}{lc}
\hline Types of Accrual Transactions & $\begin{array}{c}\text { Accrual } \\
\text { Quality }\end{array}$ \\
\hline $\begin{array}{l}\text { Converting assets to expenses transaction } \\
\text { Types of transactions observed: }\end{array}$ & $38.70 \%$ \\
inventory expense transaction (consumption of inventories). & \\
depreciation expense of fixed assets transaction (consumption of fixed assets). & $41.44 \%$ \\
amortization expense transaction (consumption of intangible assets). & $38.04 \%$ \\
converting prepaid expense to expense. & $36.05 \%$ \\
& $39.04 \%$ \\
Accruing unpaid expensestransaction & $46.22 \%$ \\
Types of transactions observed: & \\
unpaid salaries and allowances expense transaction. & $45.10 \%$ \\
unpaid overtime work fee expense transactions. & $55.56 \%$ \\
unpaid utilities expense transactions. & $41.47 \%$ \\
cleaning services/security/catering expense transactions. & $55.65 \%$ \\
Accruing unpaid assets transaction & $68.45 \%$ \\
Types of transactions observed: & \\
unpaid acquisition of inventories transactions. & $66.42 \%$ \\
unpaid acquisition of fixed assets transactions. & $69.88 \%$ \\
unpaid acquisition of intangible assets transactions. & $68.00 \%$ \\
Accruing uncollected revenues transaction & $55.51 \%$ \\
Types of transactions observed: & \\
uncollected tax revenues transactions. & $62.32 \%$ \\
uncollected charges revenues transactions. & $63.27 \%$ \\
uncollected dividend income transactions on investments. & $42.38 \%$ \\
uncollected interest revenues/fine revenues/claims revenues transactions. & $42.01 \%$ \\
Converting liabilities to revenues transaction & $36.58 \%$ \\
Types of transactions observed: & $36.58 \%$ \\
converting of prepaid income to revenue. & $48.57 \%$ \\
All types of transactions & \\
\hline
\end{tabular}

Based on Table 1, the total implementation quality score of accrual accounting performance for all types of transactions is $48.57 \%$. This shows that the quality of accrual accounting implementation in local government in Indonesia is still low. This result is consistent with Ismiyati and Ritonga (2016). Furthermore, the score for the type of accruing unpaid assets transaction, obtained the highest score of $68.45 \%$. This shows that the implementation of accrual accounting on the type of accruing unpaid assets transaction is the type of transaction with the best quality of accrual accounting implementation. Meanwhile, the score for the type of converting liabilities to revenues transaction, get the lowest score of $36.58 \%$. This shows that the implementation of accrual accounting on the type of converting liabilities to revenues transaction is the type of transaction with the worst quality of accrual accounting implementation. 
The highest score for the unpaid acquisition of fixed assets transactions is $69.88 \%$. This shows that the implementation of accrual accounting on unpaid acquisition of fixed assets transactions is a transaction with the best quality of accrual accounting implementation. Meanwhile, the score for amortization expense transactions (consumption of intangible assets), has the lowest score of $36.05 \%$. This indicates that the implementation of accrual accounting on amortization expense transactions (consumption of intangible assets) is a transaction of observation with the worst quality of accrual accounting implementation.

Further analysis. Further analysis on the quality of accrual accounting implementation discusses the quality of accrual accounting implementation between local governments that have unqualified opinions and qualified opinions and comparison of accrual accounting quality among local government.

1. Quality difference of accrual accounting implementation betweenlocal governments with unqualified opinions and local governments with qualified opinions.

This research was conducted on 88 local governments with unqualified opinions and 28 local governments with qualified opinions for fiscal year 2015. This opinion is based on SAB audit for the local government financial report 2015. The average score of accrual accounting in those local governments are presented in the Tabel 2 below.

Table 2. Average score of quality of accrual accounting

\begin{tabular}{lrr}
\hline Opinion & $\begin{array}{c}\text { Number of Local } \\
\text { Governments }\end{array}$ & $\begin{array}{c}\text { Average Score of Accrual } \\
\text { Quality }\end{array}$ \\
\hline Unqualified & 88 & $47.41 \%$ \\
Qualified & 28 & $46.61 \%$ \\
\hline
\end{tabular}

Table 2 shows that there is no significant difference between local government with unqualified opinion and those with qualified opinion. This fact is supported with output of t-test. The p-value of 0.933 (above 0.05 ) indicating that there's no significant difference in accrual accounting quality between local governments with unqualified opinions and local governments qualified opinions. This fact indicates that the Supreme Audit Board of RI might be does not considered yet the quality of accrual accounting in formulating opinion.

2. Quality difference of accrual accounting implementation among types of local governments.

There are three types of local government in Indonesia, which are regency local government, municipal local government, and provincial local government. This research was conducted on 55 regency local governments, 36 municipal local governments, and 25 provincial local governments. The average score of the quality of accrual accounting implementation in each type of local government is presented in the Table 3 below.

Table 3. Average score of accrual accounting quality

\begin{tabular}{lrr}
\hline Type of Local Governments & $\begin{array}{c}\text { Number of Local } \\
\text { Governments }\end{array}$ & $\begin{array}{c}\text { Average Score of } \\
\text { Accrual Quality }\end{array}$ \\
\hline Regency Local Government & 55 & $45.70 \%$ \\
Municipal Local Government & 36 & $49.05 \%$ \\
Provincial Local Government & 25 & $47.94 \%$ \\
\hline
\end{tabular}


Table 3 shows that the quality of accrual accounting implementation in municipal local government is higher than that of provincial local government and regency local government. However, this difference is not significant. Based on the output of ANOVA test, see Table 4 below, the p-value of 0.670 (above 0.05 ) indicating that there is no significant difference in accrual accounting quality among each types of local governments. This condition indicates that organization complexity, size of budget, and number of transactions might not influence accrual accounting quality. However, this fact might give signal that there is no significant difference of accounting knowledge among accounting managers for each types of local government.

Table 4. Output of ANOVA test ANOVA

Data_Transformasi

\begin{tabular}{|l|r|r|r|r|r|}
\hline & \multicolumn{1}{|c|}{$\begin{array}{c}\text { Sum of } \\
\text { Squares }\end{array}$} & \multicolumn{1}{c|}{ df } & Mean Square & F & Sig. \\
\hline Between Groups &, 008 & 2 &, 004 &, 401 &, 670 \\
Within Groups & 1,064 & 113 &, 009 & & \\
Total & 1,071 & 115 & & & \\
\hline
\end{tabular}

\section{CONCLUSION}

Based on the analysis described in the previous section, the conclusions of this research are as follows, first, the quality of accrual accounting implementation in local government in Indonesia is still low with quality level of $48.57 \%$. This indicates that the majority of accrual transactions are not recognized on time. Second, there is no significant difference in the quality of accrual accounting implementation in local government with unqualified opinions and local government with qualified opinions. This fact indicates that the Supreme Audit Board of RI might be does not considered yet the quality of accrual accounting in formulating opinion. Third, there is no significant difference in the quality of accrual accounting between regency local government, municipal local government, and provincial local government. This condition indicates that organization complexity size of budget and transaction might not influence accrual accounting quality.

Result of this research are expected to give contribution to some parties. First, for local government, these research results can be used as a reference to improve accrual accounting practices. Second, for Governmental Accounting Standards Committee, these research results can be used as a reference in the development and improvement of GAS. Third, for Ministry of Domestic Affairs, these research results can be used as a basis in conducting coaching (e.g. in the form of making guidelines) so that the quality of accrual accounting implementation is getting better. Fourth, forSAB, these research results can be used as a basis for improving and developing audit procedures and audit quality.

\section{REFERENCES}

Ahn, P. D., Jacobs, K., Lim, D. W., \& Moon, K. (2014). Beyond Self-Evident: Recognising the Problematic Political Context of Accrual Accounting Adoption in 
South Korea. Financial Accountability and Management, 30(1), 25-48. https://doi.org/10.1111/faam.12026

Blöndal, J. R. (2003). Accrual Accounting and Budgeting: Key Issues and Recent Developments. OECD Journal on Budgeting, 3(1), 1608-7143. https://doi.org/10.1787/budget-v3-art4-en

BPK RI. (2015). Pendapat BPK: Kesiapan Pemerintah dalam Pelaporan Keuangan Berbasis Akrual Tahun 2015.

Broadbent, J., \& Guthrie, J. (1992). Changes in the Public Sector: A Review of Recent “Alternative” Accounting Research. Accounting, Auditing \& Accountability Journal (Vol. 5). https://doi.org/http://dx.doi.org/10.1108/09513579210011835

Carlin, T. (2005). Debating the Impact of Accrual Accounting and Reporting in the Public Sector. Financial Accountability \& Management, 21(August), 309-337. https://doi.org/10.1111/j.0267-4424.2005.00223.x

Chan, J. L. (2003). Government Accounting: An Assessment of Theory, Purposes and Standards. Public Money \& Management, 23(1), 13-20. https://doi.org/10.1111/1467-9302.00336

Chan, J. L. (2006). IPSAS and Government Accounting Reform in Developing Countries. https://doi.org/15 Janeiro 2012

Christiaens, J., \& Rommel, J. (2008). Accrual Accounting Reforms: Only for Businesslike (Parts of) Governments. Financial Accountability \& Management, 24(1), 59-75. https://doi.org/10.1111/j.1468-0408.2008.00443.x

Guthrie, J. (1998). Application of Accrual Accounting in the Australian Public Sector Rhetoric or Reality. Financial Accountability \& Management, 14(1), 1-19. https://doi.org/10.1111/1468-0408.00047

Indriantoro, N., \& Supomo, B. (2013). Metode Penelitian Bisnis (1st ed.). Yogyakarta: BPFE.

Ismiyati and Ritonga. (2016). The Evaluation of the Implementation of Accrual Based Accounting.

Lapsley, I. (1999). Accounting and the New Public Management: Instruments of Substantive Efficiency or a Rationalising Modernity? Financial Accountability and Management, 15(3\&4), 201-207. https://doi.org/10.1111/1468-0408.00081

Lapsley, I., Mussari, R., \& Paulsson, G. (2009). On the Adoption of Accrual Accounting in the Public Sector: A Self-Evident and Problematic Reform. European Accounting Review, 18(4), 719-723. https://doi.org/10.1080/09638180903334960

Marti, C. (2006). Accrual Budgeting: Accounting Treatment of Key Public Sector Items and Implications for Fiscal Policy. Public Budgeting \& Finance, 26(2), 45-65. https://doi.org/10.1111/j.1540-5850.2006.00846.x

Ouda, H. A. G. (2003). Public Sector Accounting and Budgeting Reform: The Main Issues Involved With Special Focus on The Arab World.

Pallot, J. (1992). Elements of a Theoretical Framework for Public Sector Accounting. Accounting, Auditing \& Accountability Journal, 5(1), 38-59. https://doi.org/10.1108/09513579210008244

Paulsson, G. (2006). Accrual Accounting in the Public Sector: Experiences From the Central Government in Sweden. Financial Accountability \& Management, 22(1), 47-62. https://doi.org/10.1111/j.0267-4424.2006.00392.x

Peter van der Hoek, M. (2005). From Cash to Accrual Budgeting and Accounting in the Public Sector: The Dutch Experience. Public Budgeting \& Finance, 25(1), 32-45. 
https://doi.org/10.1111/j.0275-1100.2005.00353.x

Pina, V., \& Torres, L. (2003). Reshaping public sector accounting: \{An\} International Comparative View. Canadian Journal of Administrative Sciences-Revue Canadienne Des Sciences De L Administration, 20(4), 334-350. https://doi.org/10.1111/j.19364490.2003.tb00709.x

Robinson, M. (1998). Accrual Accounting and the Efficiency of the Core Public Sector. Financial Accountability and Management, 14(1), 21-37. https://doi.org/10.1111/1468-0408.00048

Wescott, C. G. (2008). World Bank Support for Public Financial Management: Conceptual Roots and Evidence of Impact Background Paper to Public Sector Reform: What Works and Why? An IEG Evaluation of World Bank Support.

Weygandt, J.J., Kimmel, P.D., \& Kieso, D. E. (2013). Financial Accounting: IFRS Edition. USA: John Wiley \& Sons.

Wynne, A. (2007). Is the Move to Accrual Based Accounting a Real Priority for Public Sector Accounting. Public Fund Digest, 6(1), 25-39.

Wynne, A. (2008). Accrual Accounting for the Public Sector - a Fad That Has Had Its Day? International Journal on Government Financial Management, (June), 117132. 
Appendix

\title{
QUESTIONNAIRE \\ ANALYSING THE QUALITY OF ACCRUAL ACCOUNTING IMPLEMENTATION IN INDONESIA LOCAL GOVERNMENTS
}

\author{
Name of Respondent \\ Occupation \\ Name of Local Government : \\ BPK Opinion of LHP 2015 :
}

\section{Instructions}

1. Please answer the following questions honestly based on your best knowledge toward accrual accounting implementation in your local government.

2. Please answer questions by thicking-mark or circling the answer option that has been provided.

3. If you doubt when answering questions, you can contact researcher via WA / SMS at +62 85770553938 and +62 8157950979 or email at abangupi@yahoo.com/ irwanritonga@ugm.ac.id.

\section{Questions}

A. Converting Assets to Expenses Transactions

1. Is there any inventory expenses transactions (consumption of inventories) in your local government?

\section{Yes}

No

If yes, when do the inventory expenses is recognized (recorded)?
A. End of every month (June 30 or 31)
B. End of every quarter (March 31; June 30; 30 September, 31 December)
C. End of every semester (June 30; December 31)
D. End of year (December 31)

2. Is there any depreciation expenses of fixed assets transactions (consumption of fixed assets) in your local government?

$$
\text { Yes } \square \quad \text { No }
$$

If yes, when do the depreciation expenses of fixed assetsis recognized (recorded)?

A. End of every month (June 30 or 31)

B. End of every quarter(March 31; June 30; 30 September, 31 December)

C. End of every semester (June 30; December 31)

D. End of Year (December 31)

3. Is there anyamortization expensestransactions (consumption of intangible assets) in your local government?

$$
\text { Yes }
$$

No 
If yes, when do the amortization expensesof intangible assets is recognized (recorded)?

A. $\quad$ End of every month (June 30 or 31)

B. $\quad$ End of every quarter(March 31; June 30; 30 September, 31 December)

C. $\quad$ End of every semester (June 30; December 31)

D. $\quad$ End of Year (December 31)

4. Is there anyprepaid expense transactions (such as prepaid expense of insurance, prepaid expense of fuel, prepaid expense of electricity) in your local government?

Yes

No

If yes, when do the expenses due to the conversion of Prepaid Expenses is recognized (recorded)?
A.
End of every month (June 30 or 31)
B.
End of every quarter(March 31; June 30; 30 September, 31 December)
C.
End of every semester(June 30; December 31)
D.
End of Year (December 31)

\section{B. Accruing Unpaid Expenses Transactions}

5a. Is there any unpaid Salaries and Allowances expenses transaction (e.g., there are employees who have got Decree (SK) of promotion or position, but still unpaid) in your local government?

Yes No

If Yes, when do the salaries and allowances expense are recognized (recorded)?
A.
End of every month (June 30 or 31)
B.
End of every quarter(March 31; June 30; 30 September, 31 December)
C.
End of every semester(June 30; December 31)
D. $\quad$ End of Year (December 31)

5b. If the answer of 5a is Yes, is the recognition of salaries and allowances expense also followed by the recognition of salaries and allowances expenditure payable?

Yes No

If Yes, when do the salaries and allowances expenditure are recognized (recorded)?
A.
End of every month (June 30 or 31)
B. $\quad$ End of every quarter(March 31; June 30; 30 September, 31 December)
C. $\quad$ End of every semester(June 30; December 31)
D. $\quad$ End of Year (December 31)

6a. Is there any unpaidovertime work fee expenses transactions (e.g., there are employees who have worked overtime, but still unpaid) in your local government?
Yes
No

If Yes, when do the overtime work fee expenses is recognized (recorded)?
A.
End of every month (June 30 or 31)
B.
End of every quarter(March 31; June 30; 30 September, 31 December)
C.
End of every semester(June 30; December 31)
D.
End of Year (December 31) 
6b. If the answer of $6 \mathrm{a}$ is Yes, is the recognition of the overtime work fee expenses also followed by the recognition of overtime work fee expenditure payable?

Yes No

If Yes, when do the overtime work fee expenditure payable is recognized (recorded)?

A. $\quad$ End of every month (June 30 or 31)

B. $\quad$ End of every quarter(March 31; June 30; 30 September, 31 December)

C. $\quad$ End of every semester(June 30; December 31)

D. $\quad$ End of Year (December 31)

7a. Is there any unpaidutilities expenses transactions (such as electricity / water / phone / internet) which has been consumed, but still unpaid in your local government?

Yes No

If Yes, when do the utilities expenses (electricity / water / phone / internet) are recognized (recorded)?
A.
End of every month (June 30 or 31)
B.
End of every quarter(March 31; June 30; 30 September, 31 December)
C.
End of every semester(June 30; December 31)
D. $\quad$ End of Year (December 31)

7b. If the answer of 7a is Yes, is the recognition of expenses utilities (electricity / water / phone / internet) also followed by the recognition of utilities expenditure payable (electricity / water / phone / internet)?

Yes

No

If yes, when do the Utilities expenditure Payable (electricity / water / phone / internet) are recognized (recorded)?
A.
End of every month (June 30 or 31)
B. $\quad$ End of every quarter(March 31; June 30; 30 September, 31 December)
C. $\quad$ End of every semester(June 30; December 31)
D. $\quad$ End of Year (December 31)

8a. Is there anycleaning services / security / catering expenses transactions which has been consumed, but still unpaid in your local government?

Yes

No

If yes, when do the cleaning services / security / catering expenses are recognized (recorded)?
A.
End of every month (June 30 or 31)
B.
End of every quarter(March 31; June 30; 30 September, 31 December)
C.
End of every semester(June 30; December 31)
D.
End of Year (December 31)

8b. If the answer of 8a is Yes, is the recognition of cleaning services / security / catering expenses also followed by the recognition of cleaning services / security / catering expenditure payable?

$$
\text { Yes }
$$$$
\text { No }
$$ 
If Yes, when do the cleaning services / security / catering expenditure payable are recognized (recorded)?
A.
End of every month (June 30 or 31)
B.
End of every quarter(March 31; June 30; 30 September, 31 December)
C.
End of every semester(June 30; December 31)
D.
End of Year (December 31)

C. Accruing Unpaid Assets Transactions

9. Is there anyunpaid acquisition of inventories transactions in your local government?

Yes

No

If yes, when do the acquisition of an inventories are recognized (recorded)?
A. Every time it is occurred
B. End of every month (June 30 or 31)
C. End of every quarter(March 31; June 30; 30 September, 31 December)
D. End of every semester(June 30; December 31)
E. End of Year (December 31)

10. Is there anyunpaid acquisition of fixed assets transactions in your local government? Yes No

If yes, when do the acquisition of an fixed asset are recognized (recorded)?
A. Every time it is occurred
B. End of every month (June 30 or 31)
C. End of every quarter(March 31; June 30; 30 September, 31 December)
D. End of every semester(June 30; December 31)
E. End of Year (December 31)

11. Is there anyunpaid acquisition of intangible assets transactions in your local government?
Yes
No

If yes, when do the acquisition of an intangible assets are recognized (recorded)?
A. Every time it is occurred
B. End of every month (June 30 or 31)
C. End of every quarter(March 31; June 30; 30 September, 31 December)
D. End of every semester(June 30; December 31)
E. End of Year (December 31)

\section{Accruing Uncollected Revenues Transactions}

12. Is there any uncollected tax revenues transactions (that have been entitled to local government) in your local government?

Yes No

If yes, when do the uncollected tax revenue are recognized (recorded)?
A. Every time it is occurred
B. End of every month (June 30 or 31 )
C. End of every quarter(March 31; June 30; 30 September, 31 December)
D. End of every semester(June 30; December 31)
E. End of Year (December 31) 
13. Is there any uncollected charges revenues transactions (that have been entitled to local government) in your local government?

Yes

No

If yes, when do the uncollected charges revenues are recognized (recorded)?

A. Every time it is occurred

B. End of every month (June 30 or 31)

C. End of every quarter(March 31; June 30; 30 September, 31 December)

D. End of every semester(June 30; December 31)

E. End of Year (December 31)

14. Is there anyuncollected dividend income transactions on investments made by the local government (assuming the cost method) in your local government?

Yes

No

If yes, when do the uncollected dividend Income are recognized (recorded)?

A. Every time it is occurred

B. End of every month (June 30 or 31)

C. End of every quarter(March 31; June 30; 30 September, 31 December)

D. End of every semester(June 30; December 31)

E. End of Year (December 31)

15. Is there anyuncollected interest revenues / fine revenues / claims revenues transactions, in your local government?

Yes

No

If yes, when do the uncollected interest revenues / fine revenues / claims revenues are recognized (recorded)?

A. End of every month (June 30 or 31)

B. End of every quarter(March 31; June 30; 30 September, 31 December)

C. End of every semester(June 30; December 31)

D. End of Year (December 31)

\section{E. Converting Liabilities to Revenues Transactions}

16. Is there anyprepaid revenue transactions (such as prepaid rent revenues) in your local government?

Yes

No

If yes, when do the converting of prepaid income to revenue are recognized (recorded)?

A. End of every month (June 30 or 31)

B. End of every quarter(March 31; June 30; 30 September, 31 December)

C. End of every semester(June 30; December 31)

D. End of Year (December 31)

Thank you for your participation in this research 